term infants. We found that: (1) Ti is more prolonged with resistive than with elastic loads; (2) $\mathrm{T}$ tends to increase with loading, more so with resistive loads; and (3) peak nasal pressure is greater with resistive than with elastic loads. These findings suggest that: (1) control of $\mathrm{Ti}$ is flow dependent; (2) instantaneous frequency tends to decrease with loading; and (3) if peak nasal pressure reflects tension developed by the respiratory muscles, the latter does not represent the inhibitory information needed to terminate inspiration.

\section{REFERENCES AND NOTES}

1. Adler, S. M., Thach, B. T., and Frantz, I. D.: Ventilatory stability of the premature infant. Pediat. Res., 9: 393 (1975).

2. Bradley, G. W.: The response of the respiratory system to elastic loading in cats. Resp. Physiol., 16: 142 (1972).

3. Bryan, A. C.: Personal communication.

4. Davies, H. W., Haldane, J. S., and Priestley, J. G.: The response to respiratory resistance. J. Physiol., 53: 60 (1919).

5. Finer, N. N., Abroms, I. F., and Taeusch, H. W., Jr.: Influence of sleep state on the control of ventilation [Abstract]. Pediat. Res., 9: 365 (1975).

6. Freedman, S., and Campbell, E. J. M.: The ability of normal subjects to tolerate added inspiratory loads. Resp. Physiol., 10: 213 (1970).

7. Freedman, S.: The effects of added loads in man: conscious and anesthetized. In: L. D. Pengelly, A. S. Rebuck, and E. J. M. Campbell: Loaded Breathing, p. 23 (Longman Canada Ltd., Hamilton, Canada, 1973).

8. Margaria, C. E., Iscoe, S., Pengelly, L. D., Couture, J., Don, H., and MilicEmili, J.: Immediate ventilatory response to elastic loads and positive pressure in man. Resp. Physiol., 18: 347 (1973).

9. McClelland, A. R., Sproule, B. J., and Lynne-Davies, P.: Functional importance of the Breuer-Hering reflex. Resp. Physiol., 15: 125 (1972).

10. McIlroy, M. B., Eldridge, F. L., Thomas, J. P., and Christie, R. V.: The effect of added elastic and non-elastic resistances on the pattern of breathing in normal subjects. Clin. Sci., 15: 332 (1956).

11. Mead, J.: Control of respiratory frequency. J. Appl. Physiol., 15: 325 (1960).
12. Olinsky, A., Bryan, M. H., and Bryan, A. C.: Influence of lung inflation on respiratory control in neonates. J. Appl. Physiol., 36: 426 (1974).

13. Olinsky, A., Bryan, M. H., and Bryan, A. C.: Response of newborn infants to added respiratory loads. J. Appl. Physiol., 37: 190 (1974).

14. Otis, A. B., Fenn, W. O., and Rahn, H.: Mechanics of breathing in man. J. Appl. Physiol., 2: 592 (1950).

15. Pengelly, L. D., Alderson, A. M., and Milic-Emili, J.: Mechanics of the diaphragm. J. Appl. Physiol., 30: 797 (1971).

16. Pope, H., Holloway, R., and Campbell, E. J. M.: The effects of elastic and resistive loading of inspiration on the breathing of conscious man. Resp. Physiol., 4: 363 (1968).

17. Read, D. J. C., Freedman, S., and Kafer, E. R.: Pressures developed by loaded inspiratory muscles in conscious and anesthetized man. J. Appl. Physiol., 37: 207 (1974)

18. Rigatto, H., and Brady, J. P.: Periodic breathing and apnea in preterm infants. I. Evidence of hypoventilation possibly due to central respiratory depression. Pediatrics, 50: 202 (1972)

19. Shannon, R., Zechman, F. W., and Frazier, D. T.: First-breath response of medullary inspiratory neurones to the mechanical loading of inspiration. Resp. Physiol., 16: 70 (1972)

20. Wiley, R. S., and Zechman, Jr., F. W.: Initial responses to added viscous resistance to inspiration in dogs. J. Appl. Physiol., 20: 160 (1965).

21. Zechman, F., Hall, F. G., and Hull, W. E.: Effects of graded resistance to tracheal air flow in man. J. Appl. Physiol., 10: 356 (1957).

22. We are grateful to Dr. V. Chernick for his invaluable comments, to Mrs. M. MacCallum and Mr. D. Cates for technical assistance, and to Mrs. M. Szajcz for typing and helping in the preparation of the manuscript.

23. Dr. Rodney B. Boychuk is a Medical Research Council Fellow.

24. Dr. Mary M. K. Seshia is a Research Fellow in Neonatology.

25. This research was supported by the Medical Research Council of Canada Grant MA-4980 and by the Children's Hospital of Winnipeg Research Foundation, Inc.

26. Requests for reprints should be addressed to: H. Rigatto, M.D., Department of Paediatrics, Women's Centre, 700 Wiiliam Ave., Winnipeg, Manitoba R3E 0Z3 (Canada)

27. Received for publication May 4, 1976

28. Accepted for publication September 15, 1976.
Hypoglycemia

liver mitochondria pyruvate carboxylase pyruvate dehydrogenase Reye's syndrome

\title{
Deficient Activity of Hepatic Pyruvate Dehydrogenase and Pyruvate Carboxylase in Reye's Syndrome
}

\author{
BRIAN H. ROBINSON, ${ }^{(25)}$ D. GRANT GALL, AND ERNEST CUTZ
}

Departments of Paediatrics, Biochemistry, and Pathology, University of Toronto; Research Institute, The Hospital for Sick Children, Toronto, Ontario, Canada

\section{Summary}

The activity of certain hepatic enzymes involved in carbohydrate metabolism was measured in postmortem samples from six cases of Reye's symdrome. The activities of the two exclusively extramitochondrial enzymes, glucose-6-phosphatase and fructose-1,6-diphosphatase, were all within the normal range. Activities of pyruvate carboxylase and pryuvate dehydrogenase, both of which are exclusively mitochondrial enzymes, were below levels shown by control tissue in every case, the average being $\mathbf{2 1 . 7 \%}$ of the lowest control value for pyruvate carboxylase and $11.6 \%$ of that for pyruvate dehydrogenase. Impaired pyruvate metabolism appears to be another feature in Reye's syndrome.

\section{Speculation}

The hypoglycemia and lactic acidemia frequently observed in Reye's syndrome are due to decreased activity in the mitochondria of pyruvate carboxylase and pyruvate dehydrogenase, respectively.

Reye's syndrome exhibits a number of features which are indicative of gross hepatic damage including elevated blood ammonia $(1,10)$ and serum glutamic oxalic transaminase (2), hypoglycemia (15), and clotting abnormalities (5). At the same time, liver tissue from patients with Reye's syndrome demon- 
strates diffuse small droplet fatty change of hepatocytes without necrosis or associated inflammatory lesions and ultrastructural changes of mitochondria (11). These findings correlate with observations of decreased activity in two urea cycle enzymes present in liver mitochondria, ornithine transcarbamylase (EC. 2.1.3.3) $(7,18,20,22)$ and carbamyl phosphate synthetase (EC. 2.7.2.5) (7, 18). Histochemical observation of succinate dehydrogenase (EC. 1.3.99.1) and cytochrome oxidase (EC 1.9.3.1) in Reye's syndrome has shown that these mitochondrial enzymes are also deficient in activity (3). In this report we extend the biochemical observations to include the virtual absence of two further specific mitochondrial enzymes in this disease.

\section{CASE MATERIAL}

Informed parental consent was obtained in all cases in which postmortem tissues from six patients with Reye's syndrome and from seven control subjects were studied. The group with Reye's syndrome consisted of three females and three males. Their clinical and laboratory findings are summarized in Table 1 . All five patients demonstrated the classic prodromal illness followed by confusion, drowsiness, and rapid onset of encephalopathy as described by Reye et al. (15). In addition, they all showed elevated serum transaminases and blood ammonia. Low blood glucose was evident $(<60 \mathrm{mg} / 100 \mathrm{ml})$ in four of the cases. In all six patients the diagnosis of Reye's syndrome was confirmed by the demonstration of characteristic diffuse small droplet fatty infiltration of liver, swollen mitochondria with loss of cristae, and absence of centrilobular necrosis (9).

\section{MATERIALS AND METHODS}

Liver tissue was obtained at autopsy within $2 \mathrm{hr}$ after death, frozen in liquid nitrogen, and stored at $-100^{\circ}$ until used for determinations. Tissue stored in this way showed no loss of enzyme activity over an 18-month period. For the enzyme assays to be listed below, small pieces of tissue were thawed, homogenized in 10 volumes of ice-cold $0.25 \mathrm{M}$ sucrose, $5 \mathrm{mM}$ Tris- $\mathrm{HCl}$ buffer, pH 7.4, and centrifuged at $500 \times g$ for $10 \mathrm{~min}$ to remove cell debris. Glucose-6-phosphatase was measured by the method of Swanson (20), fructose-1,6-diphosphatase by the method of Pontremoli (14), phosphoenolpyruvate carboxykinase by the method of Roobol and Alleyne (17), and pyruvate carboxylase by the method of Crabtree $e t$ al. (8).

The assay of whole tissue pyruvate dehydrogenase activity was carried out as described by Taylor et al. (21) using 300 to $400 \mathrm{mg}$ freshly thawed tissue, homogenized in 10 volumes of ice-cold buffer, containing $10 \mathrm{mM}$ potassium phosphate, $1 \mathrm{mM}$ EDTA, 1 $\mathrm{mM}$ dithiothreitol, and $1 \%$ fatty acid free bovine serum albu$\mathrm{min}, \mathrm{pH} 7.4$. Aliquots of $0.1 \mathrm{ml}$ were then added to assay buffer (11 mM potassium phosphate, $1.1 \mathrm{mM}$ EDTA, $2.8 \mathrm{mM} \mathrm{MgCl}_{2}$, $1.6 \%$ bovine serum albumin (fatty acid free), $1.2 \mathrm{mM}$ dithiothreitol, $0.3 \mathrm{mM}$ pyruvate labeled with $0.12 \mu \mathrm{Ci}$ ${ }^{14} \mathrm{C}$ pyruvate/ml at $\mathrm{pH} 7.4$ and $37^{\circ}$ ). The flasks were fitted with plastic inserts holding strips of filter paper $(1 \times 3 \mathrm{~cm})$ saturated with $0.2 \mathrm{ml}$ hyamine and closed with a rubber stopper. The reaction was stopped after a given time by injecting $0.8 \mathrm{ml} 0.08$ $\mathrm{M}$ citric acid, $0.04 \mathrm{M} \mathrm{Na}_{2} \mathrm{HPO}_{4}$ buffer (pH 3.0). After $30 \mathrm{~min}$ of further incubation the filter strips were removed with forceps and placed in $10 \mathrm{ml}$ toluene-ethanol $(9: 1 \mathrm{v} / \mathrm{v})$ scintillation fluid and the ${ }^{14} \mathrm{C}$ activity measured in a Beckman liquid scintillation spectrometer.

\section{RESULTS}

The activities of the key gluconeogenic enzymes in postmortem liver plus that of pyruvate dehydrogenase are shown in Table 2 . The acitvities of the two exclusively extramitochondrial enzymes, glucose-6-phosphatase and fructose-1,6-diphosphatase, were all within the normal range except for the diphosphatase activity of case 2 , which was just outside the range of our controls, $0.59 \mu \mathrm{mol} / \mathrm{min} / \mathrm{g}$ liver, compared with the lowest value in control tissue of 0.72 . Activities of phosphoenolpyruvate carboxykinase, which has a bimodal distribution in man with approximately equal activities in both the mitochondrial and cytosolic compartments (4), were also within the range shown by controls except that case 2 was again slightly below the lowest value exhibited in control tissue. Activities of pyruvate carboxylase and pyruvate dehydrogenase, both of which are exclusively

Table 1. Clinical summary'

\begin{tabular}{|c|c|c|c|c|c|c|}
\hline Patient & Age & Sex & Serum $\mathrm{NH}_{3}, \mu \mathrm{g} / \mathrm{dl}$ & SGOT, units/ml & $\begin{array}{c}\text { Blood glucose, } \\
\mathrm{mg} / \mathrm{dl}\end{array}$ & $\begin{array}{c}\text { Days from onset } \\
\text { of encephalop- } \\
\text { athy to death }\end{array}$ \\
\hline 1 & $14 \mathrm{yr}$ & $\mathbf{F}$ & 448 & 305 & 116 & 4 \\
\hline 2 & $6 \mathrm{yr}$ & $\mathbf{M}$ & 587 & 1,512 & 48 & 3 \\
\hline 3 & $10 \mathrm{mo}$ & $\mathbf{F}$ & 790 & 1,110 & 36 & 3 \\
\hline 4 & $11 \mathrm{yr}$ & $\mathbf{F}$ & 199 & 2,500 & 108 & 4 \\
\hline 5 & $3 \mathrm{yr}$ & $\mathbf{M}$ & 638 & 1,080 & 55 & 4 \\
\hline Normal subjects & & & $<100$ & $<60$ & & \\
\hline
\end{tabular}

${ }^{1}$ Values given are for the lowest blood glucose and the highest $\mathrm{NH}_{3}$ and serum glutamic oxalacetic transaminase (SGOT) recorded during the admission.

Table 2. Enzyme activities in postmortem liver (micromoles per $\mathrm{g}$ per min)'

\begin{tabular}{|c|c|c|c|c|c|c|c|c|}
\hline \multirow[b]{2}{*}{ Enzyme } & \multicolumn{6}{|c|}{ Patient } & \multirow{2}{*}{$\begin{array}{c}\text { Controls }{ }^{2} \text { (mean } \\
+ \text { SEM) }\end{array}$} & \multirow[b]{2}{*}{ Range } \\
\hline & $l$ & 2 & 3 & 4 & 5 & 6 & & \\
\hline G6Pase & 1.98 & 1.62 & 3.40 & 3.67 & 2.10 & 4.10 & $2.55 \pm 0.52$ & $(1.19-4.80)$ \\
\hline F16Dpase & 1.95 & 0.59 & 2.25 & 2.44 & 1.46 & 0.62 & $1.40 \pm 0.34$ & $(0.72-3.20)$ \\
\hline PEPCK & 0.94 & 0.59 & 1.70 & 2.43 & 1.79 & 0.91 & $1.89 \pm 0.44$ & $(0.69-3.21)$ \\
\hline Pyruvate carboxylase & 0.097 & 0.004 & 0.230 & 0.240 & 0.092 & 0.218 & $0.91 \pm 0.16$ & $(0.61-1.66)$ \\
\hline Pyruvate dehydrogenase & 0.011 & 0.052 & 0.041 & 0.048 & 0.233 & 0.055 & $0.77 \pm 0.10$ & $(0.645-1.256)$ \\
\hline
\end{tabular}

' G6Pase: glucose-6-phosphatase; F16Dpase: fructose-1,6-diphosphatase; PEPCK: phosphoenolpyruvate carboxylase.

${ }^{2}$ Control tissue was from seven individuals all less than 10 years of age taken at autopsy within 2 hr of death and showing no signs of liver disease. 
mitochondrial enzymes, were below the levels shown by control tissue in every case, the average being $21.7 \%$ of the lowest control value for pyruvate carboxylase and $11.6 \%$ of that for pyruvate dehydrogenase. Preincubation of tissue extracts with $\mathrm{Ca}^{++}$and $\mathrm{Mg}^{++}$as described by Robinson and Sherwood (16) to elicit maximal pyruvate dehydrogenase activity resulted in only slight $(<10 \%)$ increase in activity in tissue from both patients and control subjects.

\section{DISCUSSION}

Defective urea cycle function in a damaged liver leading to hyperammonemia has been suggested as central to the pathogenesis of encephalopathy in Reye's syndrome $(18,19,22)$, although it has now been shown that the activities of hepatic ornithine transcarbamylase and carbamyl phosphate synthetase slowly return to normal after the acute phase of the disease (7, 18). This is so whether or not the progression of the disease leads to fatality (7). However, ultrastructural changes and reduction of succinic oxidase and cytochrome oxidase activities suggest that a more general demise in mitochondrial function may be one of the early events in this disease $(3,13)$. Hypoglycemia exhibited in Reye's syndrome (15) thought to be related to depletion of hepatic glycogen reserves, may be due, at least in part, to impaired gluconeogenesis (11). Failure to convert 3carbon substrates such as pyruvate, alanine, and lactate into glucose leads to an accumulation of those metabolites (12). Thus, impaired pyruvate metabolism appears to be another feature in Reye's syndrome.

The results presented demonstrate abnormalities of two further mitochondrial enzyme pathways. First, although the extramitochondrial enzymes of gluconeogenesis such as glucose-6phosphatase and fructose-1,6-diphosphatase show normal activity in Reye's syndrome, the activity of pyruvate carboxylase, which is exclusively mitochondrial, is defective in activity. Such an impairment must mean that the gluconeogenic pathway is not operating at anywhere near its normal capacity. Second, pyruvate dehydrogenase, which allows 3-carbon substrates to be oxidized by the Krebs' cycle, is also defective in activity. This defect may be because pyruvate dehydrogenase is in the inactive form since fatty acids are the major incoming hepatic energy substrate in this disease (11). However, preincubation with $\mathrm{Ca}^{++}$ and $\mathrm{Mg}^{++}$to cause reactivation did not increase the activity to a normal level.

The observed deficiencies of ornithine transcarbamylase and carbamyl phosphate synthetase are reported to be temporary in those subjects with Reye's syndrome in which they have been measured $(7,18)$. Although it was not possible for us to make serial measurements, it is obvious from our data that in these cases which are all fatal instances, no such recovery of either pyruvate dehydrogenase or pyruvate carboxylase to normal levels was evident. We suggest that the disturbance of mitochondrial integrity by an agent or agents unknown (23) leads to a loss of enzyme activity in many metabolic pathways in which the mitochondria are involved, including the urea cycle, the Krebs' cycle, and gluconeogenesis.

\section{CONCLUSION}

The activities of two mitochondrial enzymes, pyruvate dehydrogenase and pyruvate carboxylase, were shown to be deficient in six fatal cases of Reye's syndrome. This adds credence to the postulate that nonselective deletion of mitochondrial enzymes due to disruption of mitochondrial integrity (19) is a causative factor in the pathogenesis of Reye's syndrome.

\section{REFERENCES AND NOTES}

1. Barr, R., Glass, I. H. I., and Chawla, G. S.: "Reye's Syndrome," Massive fatty metamorphosis of the liver with acute encephalopathy. Can. Med. Assoc. J. 98: 1038 (1968).

2. Bourgeois, C., Olson, L., Comer, D., Evans, H., Kaschames, N., Cotton, R. Grossman, R., and Smith, T.: Encephalopathy and fatty degeneration of the viscera: A clinico-pathologic analysis of $\mathbf{4 0}$ cases. Amer. J. Clin. Pathol., 56: 558 (1971).

3. Bove, K. E., McAdams, A. J., Partin, J. C., Partin, J. S., Hug, G., and Schubert, W. L.: The hepatic lesion in Reye's syndrome. Gastroenterology, 69: 685 (1975).

4. Brech, W., Shrago, K., and Wilken, D.: Studies on pyruvate carboxylase in rat and human tissue, Biochim. Biophys. Acta, 201: 145 (1970).

5. Brown, R. E., and Madge, G. E.: Hepatic degeneration and dysfunction in Reye's Syndrome. Amer. J. Dig. Dis., 16: 1116 (1971).

6. Brown, T., Hug, G., Bove, K., Brown, H., and Lansky, L.: Reye's syndrome. Lancet, 2: 716 (1974).

7. Brown, T., Hug, G., Lansky, L., Bove, K., Shere, A., Ryan, M., Brown, H., Schubert, W. K., Partin, J. C. and Lloyd-Still, J.: Transiently reduced activity of carbamyl phosphate synthetase and ornithine transcarbamylase in liver of children with Reye's syndrome. New Engl. J. Med., 294: 861 (1976).

8. Crabtree, B., Higgins, S. J., and Newsholme, E. A.: The acitvities of pyruvate carboxylase, phosphoenol pyruvate carboxylase and fructose-1,6-diphosphatase in muscles from vertebrates. Biochem. J., 130: 391 (1972).

9. Gall, D. G., Cutz, E., McClung, H. J., and Greenberg, M. L.: Acute liver disease and encephalopathy mimicking Reye's syndrome. J. Pediat., 87: 867 (1975)

10. Gellis, S. S., and Jones, W. A.: Case records of the Massachusetts Genera Hospital: Weekly clinicopathological exercises. New Engl. J. Med., 276: 47 (1967).

11. Glascow, A. M., Cotton, R. B., and Dhiensiri, K.: Reye's syndrome. IH. The hypoglycemia. Amer. J. Dis. Child., 125: 809 (1973).

12. Haymond, M. W., DeVivo, D. C., Karl, I. E., and Keating, J. P.: Sequential metabolic observations in Reye's syndrome. In: J. D. Pollack: Reye's Syndrome, pp. 215-225 (Grune \& Stratton, Inc., New York, 1975).

13. Partin, J. C., Schubert, W. K., and Partin, J. S.: Mitochondrial ultrastructure in Reye's syndrome (encephalopathy and fatty degeneration of viscera). New Engl. J. Med., 285: 1339 (1971).

14. Pontremoli, S.: Fructose-1,6-diphosphatase. Methods Enzymol., 9: 625 (1966).

15. Reye, R. D. K., Morgan, F., and Basel, J.: Encephalopathy and fatty degeneration of the viscera: A disease entity in childhood. Lancet, 2: 749 (1963).

16. Robinson, B. H., and Sherwood, W. G.: Pyruvate dehydrogenase phosphatase deficiency: A cause of congenital chronic lactic acidosis in infancy. Pediat. Res., 9: 935 (1975).

17. Roobol, A., and Alleyne, G. A. O.: Regulation of renal gluconeogenesis by calcium ions, hormones, and adenosine cyclic 3',5'-monophosphate. Biochem. J., 134: 157 (1973)

18. Sinatra, F., Yoshida, T., Applebaum, M., Mason, W., Hoogengrad, N. J., and Sunshine, P.: Abnormalities of carbamyl phosphate synthetase and ornithine transcarbamylase in liver of patients with Reye's syndrome. Pediat. Res., 9: 829 (1975).

19. Smith, A. L.: Ammonia disposal in Reye's syndrome. New Engl. J. Med., 294: 897 (1976).

20. Swanson, M.: Glucose-6-phosphatase from liver. Methods Enzymol., 2: 541 (1955)

21. Taylor, S. I., Mukherjie, C., and Jungas, R. L.: Studies on the mechanism of activation of adipose tissue pyruvate dehydrogenase by insulin. J. Biol. Chem., 248: 73 (1973).

22. Thaler, M. M., Hoogengrad, N. J., and Boswell, M.: Reye's syndrome due to a novel protein tolerant variant of ornithine-transcarbamylase deficiency. Lancet, 2: 438 (1974).

23. Varma, R. R., Cherayil, B., Casper, J. T., Lewis, J. D., Harrington, G., and Parker, H. W.: Short chain fatty acids (SCFA) in Reye's syndrome. Gastroenterology, 68: 1086 (1975).

24. We thank the Weston Foundation and the Canadian Medical Research Council (Grant MRC MA 5473) for their financial support.

25. Requests for reprints should be addressed to: B. H. Robinson, Ph.D., Research Institute, The Hospital for Sick Children, 555 University Ave., Toronto, Ont. M5G 1 X8 (Canada).

26. Received for publication July 13,1976

27. Accepted for publication September 2, 1976. 